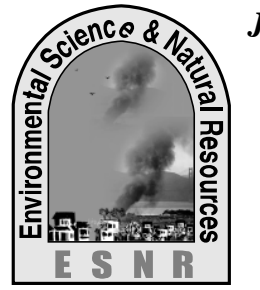

J. Environ. Sci. \& Natural Resources, 6(2): 07 - 11, 2013

ISSN 1999-7361

\title{
Status of Solid Waste Recycling at Sholokbahar Ward in Chittagong, Bangladesh
}

\author{
M. H. Kabir ${ }^{1}$, M. Ismail ${ }^{2}$ and M. Jashimuddin ${ }^{1}$ \\ ${ }^{1}$ Environmental Science, Institute of Forestry and Environmental Sciences, University of Chittagong, \\ Chittagong-4331, Bangladesh and ${ }^{2}$ Nestle (BD) Ltd.
}

\begin{abstract}
The study was conducted to analyze the solid waste recycling at Sholokbahar Ward of Chittagong City Corporation. Data were collected from primary waste collectors, i.e.Tokai, Feriwala, and Women waste collectors, waste dealers and different recycling plants through questionnaire survey and frequent field visits. The study found that the average amount of collected recyclable solid wastes was $121.37 \mathrm{~kg} / \mathrm{day}$ in each solid waste recycling shop while waste picker was about $16 \mathrm{~kg} / \mathrm{day}$. Interestingly, the amount of average collected solid waste per day by Feriwala was significantly higher than Tokai and women waste pickers. Among of recyclable solid waste about $37 \%$ was scrap iron while only $16 \%$ was plastic bottle. The study also found that solid waste pickers generally collect wastes on foot while, among Feriwala only 23\% use tricycle to collect wastes from door to door. We estimated that, by collecting recyclable solid wastes, each male and female waste picker earn, on an average, Tk. 80 and Tk.53 per day respectively. Finally, this study suggests that both governmental and non-governmental initiatives for solid waste recycling at Sholokbahar area can play a vital role to contribute our national economy, employment opportunities and environmental protection.
\end{abstract}

Keywords: Environmental protection, Income generation, Waste collection, Recycling

\section{Introduction}

Environmental degradation due to unplanned waste disposal, inadequate collection and improper waste management in urban areas was not the prime concern even a few decades ago in the developing countries especially in Bangladesh (Bhuiyanet et al., 2003).Besides, management of municipal solid waste is a substantial challenge in developing countries, in particular in the larger urban centres (Scheinberg et al., 2010).On the other hand, municipal solid waste management (MSWM) in developing countries like Bangladesh is characterized by the existence of a well-established informal sector active in collection and recycling of valuable materials (Gunsilius et al., 2011; Wilson et al., 2009).

For better MSWM, recycling can play a vital role. It is the processes of collecting, processing, remanufacturing, and reusing materials instead of discarding them. This is regarded as one of the important factors in environmental management of solid wastes for reducing the amount and space of their disposal (Rabinson, 1986; Kazemibazardehi, 1996).It helps lessen the pollution that may result from waste disposal and adds to the conservation of our resources.

Recycling is becoming an important element of solid waste management programs in many communities due to its less cost. Besides, it is a profitable business from industry to government, from schools to our household. It has been helping to keep communities clean and contribute to national economy. By bringing new partners to the recycling business, we will better our national resources, improve our quality of life, and strengthen our economy. Besides, solid waste recycling provides jobs and income to many of the urban poor who can damage the environment instead of protecting it (Richardson, 2003).

Although the informal recycling sector is seldom acknowledged for its contribution to municipal solid waste management, Gariwallas, Feriwallas and Tokais contribute largely to solid waste management in the city (Wilson et al., 2009). The government of Bangladesh states in its 3R strategy that: "It is estimated that every year Tk. 10,706 million is being saved through recycling. 120,000 urban poor from the informal sector are involved in the recycling trade chain of Dhaka City. About $15 \%$ of the total generated waste in Dhaka (mainly inorganic) amounting to 475 tons/day is recycled daily" (MoEF, 2010).

The potentials of recycling of plastic waste have made it a growing business worldwide, particularly in Bangladesh; both from economic and environmental point of view (DoE, 2010). Successful recycling must begin with an examination of the solid waste stream to determine what is recyclable. Up until now, the focus of recycling efforts has been on residential solid waste. But residential solid waste is only one portion of municipal solid waste stream. Other portion of the waste stream, such as the commercial and industrial sector, has a history of significant recycling and offer the potential for even greater recycling.

In Chittagong, second largest municipal city of Bangladesh since 1863 with a substantial, selfsustaining economic base (GOB, 2003), the average generation of solid waste in the urban areas of Chittagong is 1550 tons per day (Sinha, 2006). 
Sholokbahar ward of this city has been contributing in informal recycling sector of solid waste. Till to date, no study was conducted to analyze its status. Consequently, this study was aimed to identify materials commonly recycled in Sholokbahar along with its collection system and contribution to recycled solid waste.

\section{Methods and Materials}

\section{Selection of the area}

There are 41 wards (administrative areas) in Chittagong City Corporation (CCC). The study was selected purposively at Sholokbahar, ward number 8, under CCC of Bangladesh.

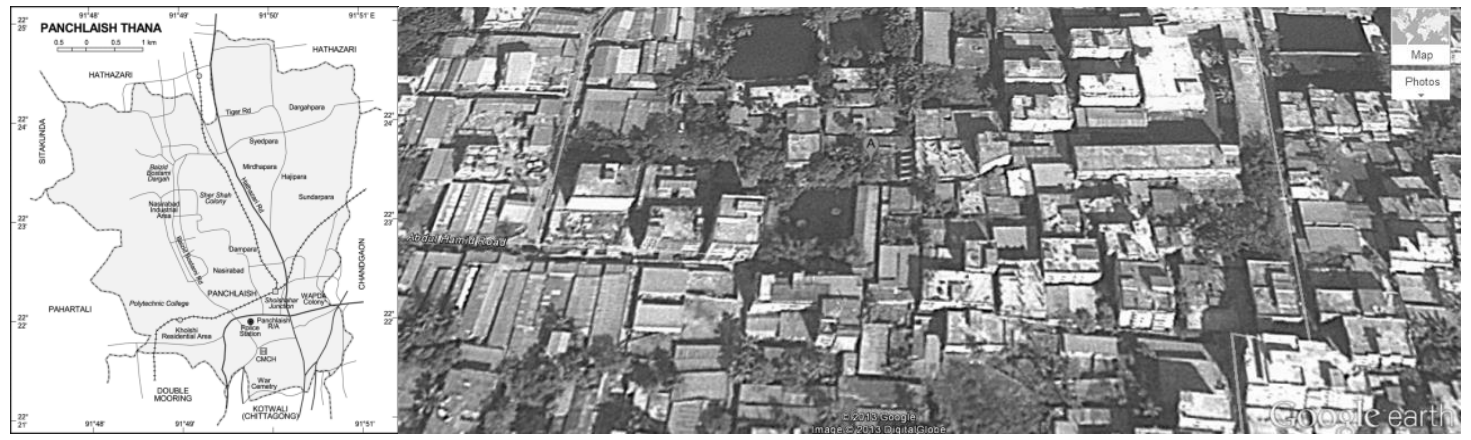

Fig. 1. Map showing the geographical location of Sholokbahar in Chittagong City Corporation (Source: Google earth)

\section{Primary data collection}

Data were collected from different sources such as primary waste collectors (Tokai, Feriwalla, and Women waste collectors), waste dealers and different recycling plants through questionnaire survey and frequent field visits. At the outset of the major work, a reconnaissance survey was done during early stage of the study in July, 2012 to identify the socio economic status and solid waste generation scenario of the study area.

Primary data were collected during the month of August, 2012 to know the qualitative and quantitative status of recycling solid waste. At Sholokbahar ward, 25 major aluminium recycling shops were visited at three different locations i.e. Mirjar pool, Boropukur, Munsipukur par. Besides, 35 Tokais, 35 Feriwalaand 20 women waste pickers were interviewed.

\section{Data compilation and analysis}

The data collected from different sources of recycling solid waste at Sholokbahar, Chittagong were carefully recorded and compiled. Finally, MS Excel and The Statistical Package for Social Science (SPSS) program were used to process and analyse the data.

\section{Results and Discussion}

\section{Estimation of average quantity of recycling materials in shop}

The collected recyclable solid waste at Sholokbahar ward of Chittagong city includes glass, metal, plastic, paper, aluminum and hazardous waste. The study found that maximum number of metal is recycled in Mirjar pool area (143.07 kg /day) while minimum was $91.05 \mathrm{~kg} /$ day at Munsipukurpar (Table 1). While the total amount of plastic waste recycled per day in DCC area stands at 91 tons/day (Waste concern, 2006).

Table 1. Estimation of average quantity of recycling materials in shop

\begin{tabular}{|c|c|c|c|c|c|c|c|c|}
\hline \multirow[t]{2}{*}{ Location of the shop } & \multirow{2}{*}{$\begin{array}{l}\text { No.of } \\
\text { shop }\end{array}$} & \multicolumn{6}{|c|}{ Average quantity of Recycling materials (Kg/day/shop) } & \multirow[b]{2}{*}{ Total } \\
\hline & & Glass & Metal & Plastic & Paper & Aluminum & $\begin{array}{l}\text { Hazardous } \\
\text { waste }\end{array}$ & \\
\hline Mirjar pool & 25 & 11 & 80 & 12 & 15 & 25 & 0.07 & 143.07 \\
\hline BoroGarej & 15 & 18 & 55 & 22 & 18 & 17 & 000 & 130 \\
\hline MunsiPukur Par & 10 & 12 & 35 & 19 & 12 & 13 & 0.05 & 91.05 \\
\hline
\end{tabular}


On the other hand, the amount of collection of paper and plastic bottle by feriwala $(12.5 \mathrm{~kg} /$ day and 4.4 $\mathrm{kg}$ /day) was significantly different from Tokai $(0.5$ $\mathrm{kg} /$ day and $0.4 \mathrm{~kg} /$ day $)$ and women waste picker $(0.5$ $\mathrm{kg}$ /day). Similar result was found both the cases of scrap iron and aluminum waste collection (Table 2).
Waste concern (2006) reported that in Dhaka city corporation (DCC) about 41tons of unsoiled plastic is collected per day by feriwallas before it is disposed, while 50.24 tons/day of soiled plastic is retrieved by different actors (van collectors, waste bin tokais, DCC collectors and dumpsite tokais) from the disposed waste of 137.57 tons/day.

Table 2. Estimation of recyclable solid waste Collected by different waste collectors

\begin{tabular}{|l|l|l|l|l|}
\hline Socio-economic groups & Paper (kg/day) & $\begin{array}{l}\text { plastic } \\
(\mathrm{kg} / \text { day })\end{array}$ & $\begin{array}{l}\text { Scrap } \\
(\mathrm{kg} / \mathrm{day})\end{array}$ & Aluminum (kg/day) \\
\hline Tokai & $0.5 \mathbf{b}^{*}$ & $0.4 \mathbf{b}$ & $1.5 \mathbf{b}$ & $0.4 \mathbf{b}$ \\
\hline Women waste picker & $0.5 \mathbf{b}$ & $0.5 \mathbf{b}$ & $1.0 \mathbf{b}$ & $0.6 \mathbf{b}$ \\
\hline Feriwala & $12.5 \mathbf{a}$ & $4.4 \mathbf{a}$ & $14.5 \mathbf{a}$ & $11 \mathbf{a}$ \\
\hline
\end{tabular}

Note: *Means followed by the same letter(s) in the same column are not significantly different at $\mathrm{P}<0.05$, Duncan's Multiple Range Test (DMRT).

\section{Physical Composition of Recyclable Solid Waste}

Among of recyclable solid waste about $37 \%$ was scrap iron while only $16 \%$ was plastic bottle. Paper recycling was about $25 \%$ of the total recycled wastes
(Fig. 2) while $51 \%$ of total plastic waste is recycled in DCC area, although health safety and environmental issues are not properly looked after (Waster concern, 2006).

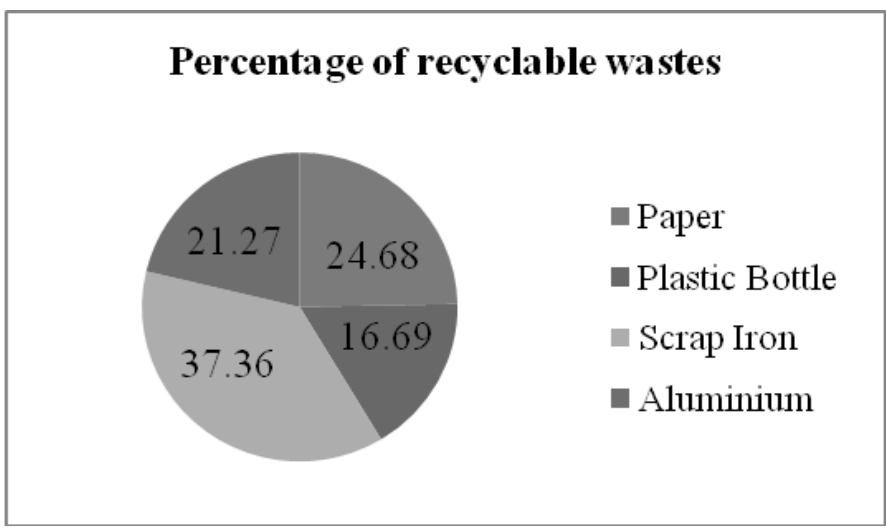

Fig. 2. Physical composition of recyclable solid wastes at Sholokbahar ward of CCC.

Interestingly, Omrany (1995) found that about 50\% of solid wastes are recyclable and recycling of solid wastes before disposal is economic which encourages the people to decrease the solid wastes and recycle them (Keynejhad and Ebrahimy, 1999).

\section{Collection of recyclable solid waste}

The study showed that every Tokai and Women waste picker of the study area collect the recyclable solid wastes manually (Fig. 3) and on foot while only $23 \%$ of Feriwala use tricycle for collecting waste (Table 3).

Table 3. Mode of transportation of recyclables of recyclables used Tokai, Ferwalla and women waste pickers

\begin{tabular}{|l|c|c|}
\hline \multirow{2}{*}{ Category } & \multicolumn{2}{|c|}{ Mode of transportation of recyclable waste } \\
\cline { 2 - 3 } & On foot (\%) & Tricycle (\%) \\
\hline Tokai & 100 & 0 \\
\hline Women waste picker & 100 & 0 \\
\hline Feriwala & 77 & 23 \\
\hline
\end{tabular}




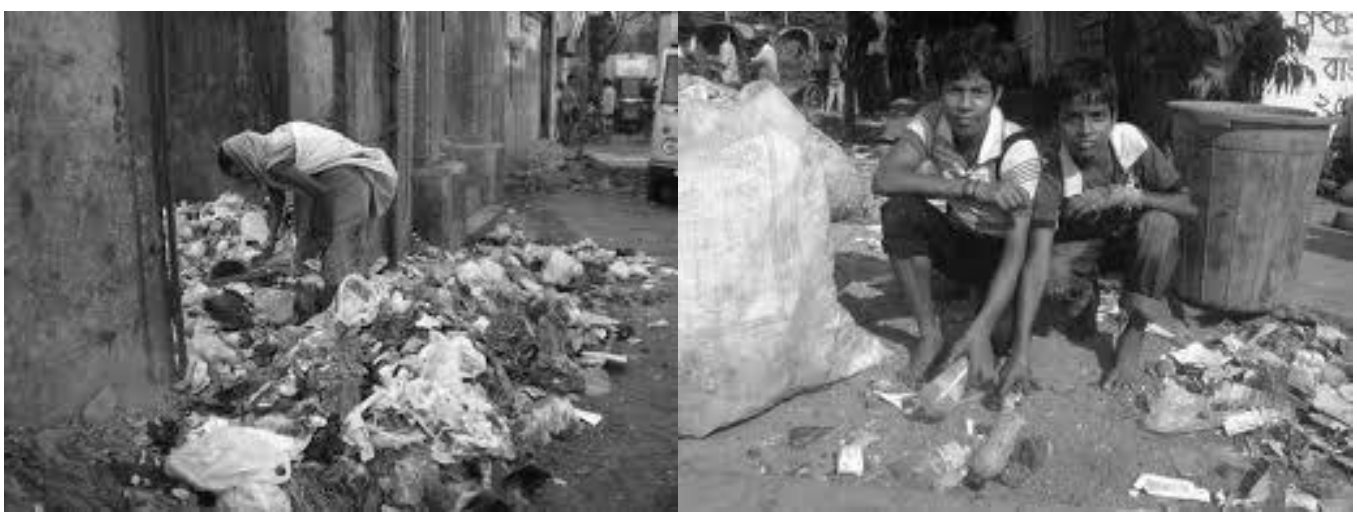

Figure 3: Manual collection of recyclable solid wastes by collectors

\section{Estimation average income of various waste collectors}

The income of different waste collectors was varied with different categories of recyclable solid waste collectors (Table 4). We found that male waste collectors earn more than female collectors with different age groups. Surprisingly, less than 12 years old Tokai male earn Tk. 40 and female earn Tk. 30 per day compared to aged (>20 years old) Feriwala (Tk. 110 per day).

Table 4. Estimation average income of various waste collectors

\begin{tabular}{|c|c|c|c|c|}
\hline \multirow[t]{2}{*}{ Socio-economic group } & \multirow[t]{2}{*}{ Age } & \multicolumn{2}{|c|}{ Income per person/day (TK.) } & \multirow{2}{*}{$\begin{array}{l}\text { Total income } \\
\text { (TK.) }\end{array}$} \\
\hline & & Male & Female & \\
\hline \multirow[b]{2}{*}{ Tokai } & $<12$ & 40 & 30 & 190 \\
\hline & $>12$ & 45 & 32 & 1330 \\
\hline Women waste picker & $>16$ & 0 & 60 & 1200 \\
\hline Feriwala & $>20$ & 110 & 0 & 3850 \\
\hline \multicolumn{4}{|c|}{$\mathbf{N}=90$} & 6570 \\
\hline
\end{tabular}

Collecting data from 90 people who made total income Tk. 6570 and average income of each waste collector wasTk. 90 taka per day. Anschutz (1996) also studied waste collectors and explains that their salary is often low because they derive their income from waste collection fees and often from the sale of recyclables.
Estimation of family supporting by waste collectors The waste collectors of the studied ward, bear their family expenses from the income generated by selling this waste. The study revealed most of the waste pickers help their family economically (Table 5). Maximum number of women waste pickers $(90 \%)$ helps their family while Feriwala $77 \%$, Tokai $(<12$ years old) $75 \%$.

Table 5. Estimation of family supporting by waste collectors

\begin{tabular}{|l|c|c|c|c|}
\hline Socio economic group & Age (years) & \multirow{2}{*}{$\begin{array}{l}\text { Number of } \\
\text { respondent }\end{array}$} & & \multicolumn{2}{|l|}{ Family Support (\%) } \\
\cline { 3 - 5 } & & & Yes & No \\
\hline Tokai & $<12$ & 35 & 51 & 25 \\
\cline { 3 - 5 } & $>12$ & 20 & 90 & 49 \\
\hline Women waste picker & $>16$ & 35 & 77 & 23 \\
\hline Feriwala & $>20$ & &
\end{tabular}

\section{Conclusion}

Solid waste recycling is predominantly in the informal sector of Bangladesh has been playing an important role not only for better municipal waste management as well as protection of environment. In Chittagong, throughout the city corporation area, recycling is a growing business. In this study, we aimed to identify the present status of solid waste recycling at Sholokbahar ward of Chittagong through interviewing the different type of recyclable waste collectors and shop owners. The study showed that very common recyclable solid waste was scrap iron (36\%) followed by paper (24\%) and aluminum 
(21\%). The collection mode of recyclable wastes was by foot. This study also found that the daily income by collection these waste were very low although most of the waste collectors (more than 75\%) earn their bread and butter for their family members. Finally, we suggest that partnership among public, private, NGOs, and civil society can improve the existing solid waste recycling in Chittagong.

\section{References}

Anschutz, J. 1996. Community-Based Solid Waste Management and Water Supply Projects: Problems and Solutions Compared: A survey of the literature. UWEP Nieuwehaven.UWEP Working Document 2.

Bhuiyan, A. H.; Nasser, E. H. and Hossain, M. 2003. Unplanned waste disposal and its possible impact on subsurface environment of Dhaka City, Bangladesh. Unpublished research paper, Department of Geological Sciences, Jahangirnagar University, Dhaka.

DoE, 2010. National 3R Strategy for Solid Waste. Department of Environment, Ministry of Environment and Forests, Government of the Peoples' Republic of Bangladesh, Dhaka, pp. 44.

GOB, 2003. Banglapedia: national encyclopedia of Bangladeshi. In: Islam, S. (Ed.), Asiatic Society of Bangladesh, Nimtali, Dhaka, Bangladesh, pp. 491-515.

Gunsilius, E.; Chaturvedi, B. and Scheinberg, A. 2011.The Economics of the Informal Sector in Solid Waste Management, CWG Collaborative Working Group on Solid Waste Management in Low- and Middle-income Countries, GIZ - Deutsche GesellschaftfürInternationaleZusammenarbeit (GIZ) GmbH.
KazemiBazardehi, M. 1996. Disposal and recycle of solid waste, Biogas composting.1st ed. Publication of Mashad Ferdousy University, Iran.

Keynejhad, A. M. and Ebrahimi, S. 1999. Environment protection engineering, vol 2. Sahand Industrial University, Iran.

Omrani, G. A. 1995. Solid waste.1st ed. Vol 2.The center of scientific publication of Islamic Azad University, Iran.

Rabinson, W. D. 1986. The solid waste Hand book: A practical Guide. John Willey, NewYork, USA.

Richardson, D. W. 2003. Community-Based Solid Waste Management Systems in Hanoi, Vietnam, MS thesis, University of Toronto, Canada, pp. 71.

Scheinberg, D.; Wilson, C. and Rodic, L. 2010. Solid Waste Management in the World's Cities, UN-Habitat's Third Global Report on the State of Water and Sanitation in the World's Cities, Earthscan.

Sinha, A. H. M. M. 2006. Community Based Solid Waste Management Through Public Private Community Partnerships: Experience of Waste Concern in Bangladesh. Paper presented in 3R South Asia Expert Workshop, Katmandu, Nepal.

Waste concern, 2006.Composition of plastic waste and market assessment of the plastic recycling sector in Dhaka city.

Wilson, D. C. Araba; Chinwah, A. O. K. and Cheeseman, C. R. 2009. Building recycling rates through the informal sector, Waste Management, 29: 629-635. 